Open Access

Res. Agric. Livest. Fish.

Research Article

Vol. 6, No. 1, April 2019 : 91-100.

\title{
EFFICACY OF PROBIOTICS ON GROWTH PERFORMANCE AND HEMATO-BIOCHEMICAL PARAMETERS IN BROILER
}

\author{
Laila Anjuman Banu, Afrina Mustari and Nazim Ahmad
}

\section{Department of Physiology, Faculty of Veterinary Science, Bangladesh Agricultural University, Mymensingh-2202, Bangladesh.}

*Corresponding author: Afrina Mustari; E-mail address: afrinadvm@gmail.com

\begin{tabular}{|c|c|}
\hline RIICLE INF & A B S T R \\
\hline $\begin{array}{l}\text { Online } \\
30 \text { April, } 2019 \\
\text { Key words: } \\
\text { Probiotics } \\
\text { Broiler } \\
\text { Growth performances } \\
\text { Haemato-biochemical }\end{array}$ & $\begin{array}{l}\text { Cobb-500 broiler chicks were used to study the effects of probiotics on growth } \\
\text { performances and haemato-biochemical parameters. A total of fifteen broiler chicks ( } 16 \\
\text { days old) were randomly divided into three equal groups }(\mathrm{n}=5) \text {. Two groups of broilers } \\
\text { were fed probiotics at the rate of } 0.5 \mathrm{gm} / \mathrm{kg} \text { and } 1 \mathrm{gm} / \mathrm{kg} \text { respectively with commercial } \\
\text { feed for } 22 \text { days. Chicks fed on only commercial feed were considered as control } \\
\text { group. The results showed that broilers treated with probiotics grew faster compared to } \\
\text { control group. After having completed the trial, the birds were sacrificed to collect blood } \\
\text { sample for hematological and biochemical analysis. Dressed weight, weight of skin } \\
\text { including feathers, leg weight, breast weight and liver weight were found higher in } \\
\text { treated groups compared to control group. Total erythrocytes count and hemoglobin } \\
\text { content were found increased in treated group compared to control group. ESR value } \\
\text { was found decrease in treated groups compared to control group. Total cholesterol, } \\
\text { triglycerides and HDL was significantly }(P>0.01) \text { lower in the treated groups compared } \\
\text { to control group. The serum alkaline phosphatase significantly }(P<0.01) \text { increased in } \\
\text { treated groups. }\end{array}$ \\
\hline
\end{tabular}

To cite this article: Banu M. L. A., A. Mustari and N. Ahmad, 2019. Efficacy of probiotics on growth performance and hemato-biochemical parameters in broiler. Res. Agric. Livest. Fish. 6 (1): 91-100.

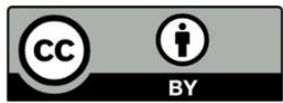

\footnotetext{
This is an open access article licensed under the terms of the Creative Commons Attribution 4.0 International License
} 


\section{INTRODUCTION}

Probiotics are live living microorganisms which, given to poultry, assist to establishment of an intestinal population which is beneficial to the poultry and antagonist to harmful microbs (Green and Sainsbury, 2001). A number of feed additives like antibiotics, growth hormones etc. have been used to improve performance of poultry. However they are no longer permitted in advanced countries in growth promoters because of their residual effects in the final products. The commercial broiler raisers mostly use commercial readymade feed. In addition, they randomly use growth promoters to have better growth of their broiler chickens. The commercial broiler feed producers add vitamins-minerals and growth promoters in required amount to feed during manufacturing. Therefore, the usefulness of supplementation of growth promoter in addition to commercial broiler feed in broilers is yet to be investigated. However, the antibiotic growth promoters have been under scrutiny for many years and have been removed from the market in many countries. Their usefulness has seldom been contested, it is their relatedness with similar antibiotics used in human medicine and the possibility that their use may contribute to the pool of antibiotic resistant bacteria that causes concerns (Philips, 1999). In light of that situation, the feed manufacturers and the animal growers have been actively looking to an efficacious alternative to antibiotic growth promoters. Probiotics improve feed conversion in broilers in comparison with un-supplemental control diets (Holoubek, 1993). The probiotics influenced on productivity in broiler production (Endo and Nakano, 1999). The profile of intestinal microflora plays an important role in gut health (Dhawale, 2005). Dietary organic acids and their salts inhibit growth of microorganisms in food and consequently, preserve microbial balance in the gastrointestinal tract. By modified intestinal $\mathrm{pH}$, organic acids improve the solubility of the feed ingredients result increased digestion and absorption of the nutrients (Patten and Waldroup, 1988).

At present, there are many probiotics available in the market and their indiscriminate use without experimental support is not justified. It is proved that a multiple species product is better than single species product. The stability of micro-flora can easily be disturbed by many factors like change in feed, vaccination, intestinal $\mathrm{pH}$, bile salt concentration in the gut and use of antibiotics. Many strains of lactic acid producing bacteria are sensitive to the antibiotics. So, the strains should be resistant to such antibiotics. It must have rapid colonizing ability and strong foothold in gut so that it can exclude by stable and have long self-life to withstand in our environmental conditions. One of such product available in the market is probiotics (BIOTOP®) claimed that they considered all these facts. So, Study is needed to evaluate the comparative effect of probiotics and growth promoter (Antibiotic growth promoter) on the performance and haemato-biochemical parameters of broiler.

\section{MATERIALS AND METHODS}

The experiment was conducted to investigate the effect of probiotics on Cobb-500 broiler chicks from day 16 to day 38 of age to assess growth performance and some biochemical such as total cholesterol, triglyceride, high density lipoprotein, alkaline phosphatase and hematological parameters as TEC, ESR and $\mathrm{Hb}$ concentration.

\section{Experimental diet}

The feeds were purchased from local market. BIO-TOP® (Daone Chemicals) is a multi-strain probiotic in dry powder from containing Bacillus subtilis, Bacillus licheni formis, which were used for supplementation of diets. Fifteen broiler chicks of 16 days were randomly divided into three equal groups $(n=5)$.

Group A-Control group fed with commercial broiler ration and fresh drinking water

Group B- commercial broiler ration + Bio-Top $^{R}(0.5 \%)$

Group C- commercial broiler ration + Bio-Top ${ }^{R}(1 \%)$

Body weight of individual bird was recorded at the beginning and at every seventh day up to the end of experiment. The birds were sacrificed to collect blood sample for hematological and biochemical analysis. 


\section{Measurement of body weight}

The body weight of each bird was measured with the help of electric balance on the day 16 of age ( 0 day of experiment) and subsequently at every seven days interval up to end of experiment.

Total weight gain in $\%=\frac{\text { Average final weight-Ararage initial weight }}{\text { Average initial weght }}$

\section{Collection of blood}

Blood from each bird was collected at slaughter. A number of sterile test tubes containing anticoagulant (3.8\% trisodium citrate solution) at a ratio of $1: 10$ were taken. About $5.0 \mathrm{ml}$ of blood was collected for hematological studies. The hematological studies were performed within two hours of collection.

\section{Preparation of serum}

About $3 \mathrm{ml}$ of blood was collected in the sterile glass test tube. The blood containing tubes were placed in a slanting position at room temperature. Then the tubes were incubated overnight in refrigerator $(40 \mathrm{C})$ and the serum was collected. The sample was centrifuged at $1000 \mathrm{rpm}$ for 15 minutes to have a more clear serum. The serum samples were separated and stored at $-200 \mathrm{C}$ till analysis.

\section{Statistical Analysis}

A randomized complete block $(\mathrm{RCB})$ design with more than one observation per cell was applied. The data were collected and the Mean \pm SE were calculated by using descriptive statistics. An analysis of variance (ANOVA) table had been constructed with the help of computer package MSTAT for identifying any statistically significant difference among the groups. The mean difference among the treatments was determined as per Dancan's Multiple Range Test (Gomez and Gomez, 1984).

\section{RESULTS AND DISCUSSION}

The experiment was conducted to study the effects of probiotics on live weight and dressed weight and weights of liver, skin, legs and hematological (total erythrocyte count, hemoglobin content, and erythrocyte sedimentation rate) and bio-chemical (total cholesterol, triglyceride, high density lipoprotein and alkaline phosphatase) parameters in broilers.

\section{Effects on growth performance}

Total body weight gain (mean \pm SE) of different groups of birds is presented in Table 1 and Figure 1. Body weight on first day of experiment (day 16) was more or less similar.

At the end of experiment the highest body weight was recorded in group $C(1460.00 \pm 85.44 \mathrm{gm}$.) followed by group B $(1426.67 \pm 75.33)$ and lowest in group A $(1186.67 \pm 80.83 \mathrm{gm}$.). The treated values differ significantly $(p<0.05)$ compared to control but differences among treated groups were insignificant $(p>0.05)$. This findings is similar to previous experiment of Hamid and Qureshi (2001) stated that protexin-treated groups had higher average live weight gains (about $121 \mathrm{~g} / \mathrm{bird}$ ) 
Table 1. (Mean \pm SE) body weight of birds in different groups on different days

\begin{tabular}{|lllll|}
\hline Broiler Groups & $\begin{array}{l}\text { Initial wt. (gm.) } \\
\text { (Day 16) }\end{array}$ & $\begin{array}{l}\mathbf{7}^{\text {th }} \text { day wt. (gm.) } \\
\text { (Day 23) }\end{array}$ & $\begin{array}{l}\mathbf{1 4}^{\text {th }} \text { day wt. (gm.) } \\
\text { (Day 30) }\end{array}$ & $\begin{array}{l}\text { Harvesting wt.(gm.) } \\
\text { (Day 37) }\end{array}$ \\
\hline $\begin{array}{l}\text { Group A } \\
\text { (Control) }\end{array}$ & $297.33 \pm 10.41$ & $720.00 \pm 26.46^{\mathrm{c}}$ & $923.33 \pm 87.37^{\mathrm{c}}$ & $1186.67 \pm 80.83^{\mathrm{c}}$ \\
$\begin{array}{l}\text { Group B } \\
\text { (Probiotics 0.5\%) } \\
\text { Group C } \\
\text { (Probiotics 1\%) }\end{array}$ & $301.33 \pm 10.41$ & $800.67 \pm 51.32^{\mathrm{a}}$ & $1150.00 \pm 70.00^{\mathrm{b}}$ & $1426.67 \pm 75.33^{\mathrm{b}}$ \\
$\begin{array}{l}\text { P value } \\
\text { (D) }\end{array}$ & 0.072 & $798.67 \pm 25.17^{\mathrm{b}}$ & $1183.33 \pm 76.38^{\mathrm{a}}$ & $1460.00 \pm 85.44^{\mathrm{a}}$ \\
& & 0.002 & 0.0001 & 0.002 \\
\hline
\end{tabular}

The values with different superscript letters $(s)$ in the same column differ significantly $(P<0.01)$

Table 2. Effects of probiotics on weights (mean \pm SE) of different organs in different groups of broiler

\begin{tabular}{|llllll|}
\hline Broiler Groups & $\begin{array}{l}\text { Wt. of legs } \\
(\mathbf{g m} .)\end{array}$ & $\begin{array}{l}\text { Wt. of liver } \\
(\mathbf{g m} .)\end{array}$ & $\begin{array}{l}\text { Dressed Wt. } \\
(\mathbf{g m} .)\end{array}$ & $\begin{array}{l}\text { Breast Wt. } \\
\text { (gm.) }\end{array}$ & $\begin{array}{l}\text { Wt. of skin } \\
\text { including } \\
\text { feathers (gm.) }\end{array}$ \\
\hline $\begin{array}{l}\text { Group A } \\
\text { (Control) }\end{array}$ & $77.69 \pm 1.68^{\mathrm{b}}$ & $32.98 \pm 4.08^{\mathrm{b}}$ & $704.94 \pm 83.35$ & $242.28 \pm 17.68$ & $163.29 \pm 13.19^{\mathrm{b}}$ \\
$\begin{array}{l}\text { Group B } \\
\text { (Probiotics 0.5\%) }\end{array}$ & $87.02 \pm 1.40^{\mathrm{a}}$ & $41.62 \pm 1.62^{\mathrm{a}}$ & $804.99 \pm 24.24$ & $251.49 \pm 9.76$ & $191.37 \pm 8.92^{\mathrm{a}}$ \\
$\begin{array}{l}\text { Group C } \\
\text { (Probiotics 1\%) }\end{array}$ & $84.742 \pm 2.99^{\mathrm{a}}$ & $42.55 \pm 0.70^{\mathrm{a}}$ & $820.79 \pm 14.91$ & $263.34 \pm 8.24$ & $194.01 \pm 6.15^{\mathrm{a}}$ \\
$\begin{array}{l}\mathrm{P} \text { value } \\
\text { Level of sig. }(\mathrm{P}<0.05)\end{array}$ & Significant & Significant & $\begin{array}{l}\text { Non- } \\
\text { Significant }\end{array}$ & $\begin{array}{l}\text { Non- } \\
\text { Significant }\end{array}$ & Significant \\
\hline
\end{tabular}

The values with different superscript letter(s) in the same column differ significantly $(p<0.05)$

Effects of Probiotics on different parts and organs of broiler are presented in table 2 and figure 2, 3, 4, 5 and 6 respectively. The leg weight (mean \pm SE) of different groups of birds is shown in Table 2 and Figure 2 . The leg weights (mean \pm SE) of control, Probiotics groups were $77.69 \pm 1.68,87.02 \pm 1.40$ and $84.74 \pm 2.99$ gm. respectively. The leg weight increased significantly $(p<0.05)$ in all treated groups compared to control. 
Fig. 1

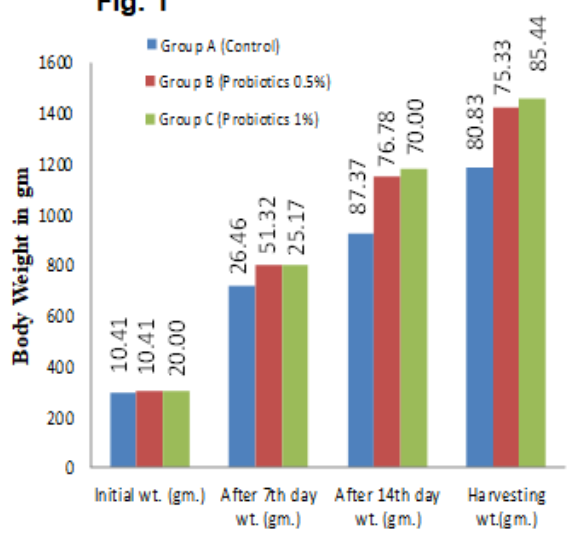

Fig. 3

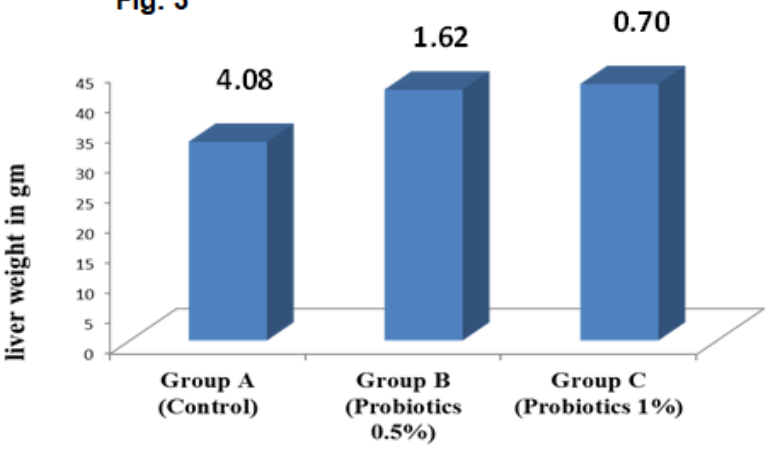

Fig. 2

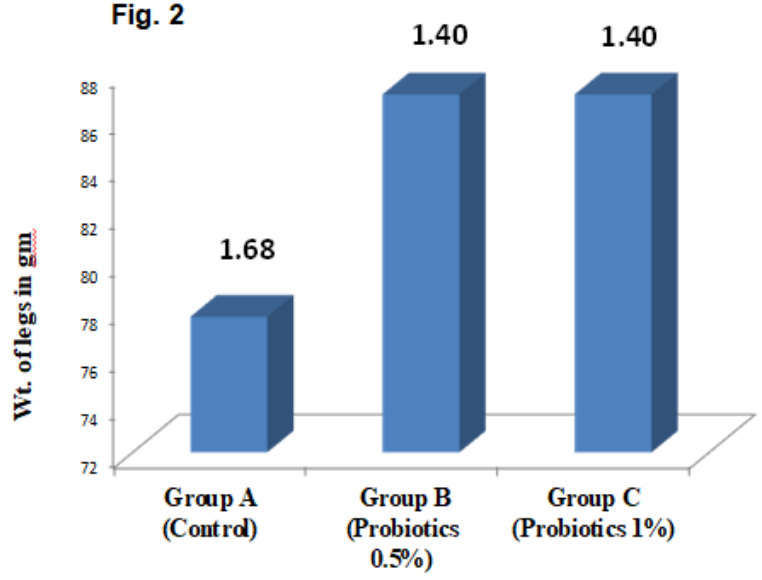

Fig. 4

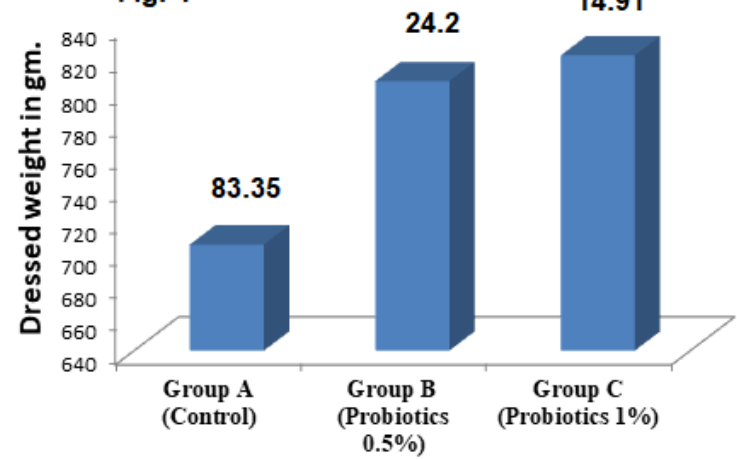

Figure 1. Effects of Probiotics on total weight (mean \pm SE) in different groups of broiler. Superscript value above bar indicate standard error; Figure 2. Effects of probiotics on leg weight (mean $\pm \mathrm{SE}$ ) of broiler. Superscript value above bar indicate standard error; Figure 3. Effects of Probiotics on liver weight (mean \pm SE) of broiler. Superscript value above bar indicate standard error; Figure 4. Effects of Probiotics on dressed weight (mean \pm SE) of broiler. Superscript value above bar indicate standard error.

The present finding is similar with the earlier experiment of Pelicano et al., (2003) who observed higher leg weight gain in birds after treatment with probiotic supplementation. Liver weight (mean \pm SE) of different groups of birds is presented in Table 2 and Figure 3 . Liver weights (mean \pm SE) of control, Probiotics groups were $32.98 \pm 4.08,41.62 \pm 1.62$ and $42.55 \pm 0.70 \mathrm{gm}$, respectively. The liver weight significantly increased in all treated groups compared to control group. The highest liver weight was recorded in group $\mathrm{C}$ and lowest in control group. Between the treated groups highest liver weight was in group $\mathrm{C}$. The present finding differs to that of Mohan et al. (1996) who observed no effects of liver weight among the groups.

The dressed weight (mean \pm SE) of different groups of birds is presented in Table 2 and Figure 4. The dressed weights (mean \pm SE) of control and probiotic groups were 704.94 $\pm 83.35,804.99 \pm 24.24$ and $820.79 \pm 14.91 \mathrm{gm}$. respectively. The dressed weights in both treated groups were increased compared to control. The highest dressed weight was recorded in group C $(820.79 \pm 14.91)$ which was followed by group B. This result shows that the group $C$ gives higher performance on dressed weight than that of group $B$ and group A.

The breast weight (mean \pm SE) of different groups of birds is presented in Table 2 and Figure 5. The breast weights (mean \pm SE) of control and probiotic groups were 242.28 $\pm 17.68,251.49 \pm 9.76$ and $263.34 \pm$ $8.24 \mathrm{gm}$, respectively. The weight was less in control group compared to other two groups. In the treated groups highest breast weight was recorded from group $\mathrm{C}$ compared to group $\mathrm{B}$. This result is contradictory findings of Baidya et al., (1994) and Mandal et al., (1994), who observed that feeding of probiotics did not have any influence on the carcass yield. Pelicano et al., (2003) observed that feeding of different probiotics influence on carcass and meat quality of broilers. 
The skin weight including feathers (mean \pm SE) of different groups of birds is presented in Table 2 and Figure 6. The skin weight including feathers (mean \pm SE) of control and probiotic groups were $163.29 \pm 13.19$, $191.37 \pm 8.92$ and $194.01 \pm 6.15 \mathrm{gm}$, respectively. The skin weight including feathers observed lowest in control group significantly $(\mathrm{P}<0.05)$ compared to other two groups. In the treated groups highest skin weight including feathers was recorded from group $\mathrm{C}$ compared to group $\mathrm{B}$. It is differed from the earlier findings of Datta (2013) who observed that skin weight including feather were group A $(160 \pm 23.85 \mathrm{~g})$, group B $(280 \pm 12.71 \mathrm{~g})$ group C $(285 \pm 11.42 \mathrm{~g})$, group D $(280 \pm 9.25 \mathrm{~g})$ and group $\mathrm{E}(277 \pm 17.65 \mathrm{~g})$.

\section{Effects on hematological parameters}

The effects of on hemoglobin concentration, erythrocyte sedimentation rate (ESR) and total erythrocyte count are presented in table 3 and figures 7,8 , and 9, respectively.

Table 3. Effects of Probiotic on hematological parameters (mean \pm SE) in different groups of broilers. Values with different superscript litter(s) in the same column differ significantly $(P<0.05)$

\begin{tabular}{|c|c|c|c|}
\hline Broiler Groups & TEC(Million/mm ) & ESR ( $\mathrm{mm}$ in first hour) & $\mathrm{Hb}(\mathrm{gm} / \mathrm{dl})$ \\
\hline $\begin{array}{l}\text { Group A } \\
\text { (Control) }\end{array}$ & $2.0 \pm 0.10^{c}$ & $6.00 \pm 0.07^{a}$ & $7.07 \pm 0.12$ \\
\hline $\begin{array}{l}\text { Group B } \\
\text { (Probiotics 0.5\%) }\end{array}$ & $2.3 \pm 0.11^{b}$ & $5.17 \pm 0.58^{a}$ & $7.13 \pm 0.12$ \\
\hline $\begin{array}{l}\text { Group C } \\
\text { (Probiotics 1\%) }\end{array}$ & $2.5 \pm 0.13^{b}$ & $4.67 \pm 0.58^{b}$ & $7.33 \pm 0.31$ \\
\hline$P$ value & 0.016 & 0.031 & 0.067 \\
\hline Level of sig. $(\mathrm{P}<0.05)$ & Non significant & Non significant & Non significant \\
\hline
\end{tabular}

Total erythrocyte counts of different groups of birds are shown in in Table 3 and Figure 7. The total erythrocyte count (TEC) in control group was $2.0 \pm 0.10 \mathrm{million} / \mathrm{mm} 3$, group B was $2.3 \pm 0.11 \mathrm{million} / \mathrm{mm}$ and group $C$ was $2.5 \pm 0.13$ million/mm3. Significant $(p<0.05)$ differences were observed among the treated groups compared to control group. The total erythrocyte count (TEC) in control group varied significantly $(p<0.05)$ from all other groups.

Erythrocyte sedimentation rate (mean \pm SE) of different groups of birds is presented in Table 3 and Figure 8. Erythrocyte sedimentation rate of group A, group B and group C were $4.67 \pm 0.58,5.17 \pm 0.58$ and $6.00 \pm$ 0.07 respectively. The highest erythrocyte sedimentation rate (ESR) was in found $C$ and lowest was found in control group (group A). The hemoglobin content (mean $\pm \mathrm{SE}$ ) in different groups of broilers is presented in Table 3 and Figure 9. The hemoglobin $(\mathrm{Hb})$ content in control group was $7.07 \pm 0.12 \mathrm{gm} \%$, group B was 7.13 $\pm 0.12 \mathrm{gm} \%$, and group $\mathrm{C}$ was $7.33 \pm 0.31 \mathrm{gm} \%$. The highest hemoglobin content was recorded in group C and lowest in control group.

The results of hematological parameters are in agreement with the findings of Kamruzzaman et al., (2005) and Islam et al., (2004) who stated that the mean values of TEC, ESR and Hb corresponding to the different treatments (group A control, group B $0.5 \mathrm{~g}$ probiotic/liter drinking water, group C $0.5 \mathrm{~g}$ growth promoter/liter drinking water) were differ significantly $(p<0.05)$. 


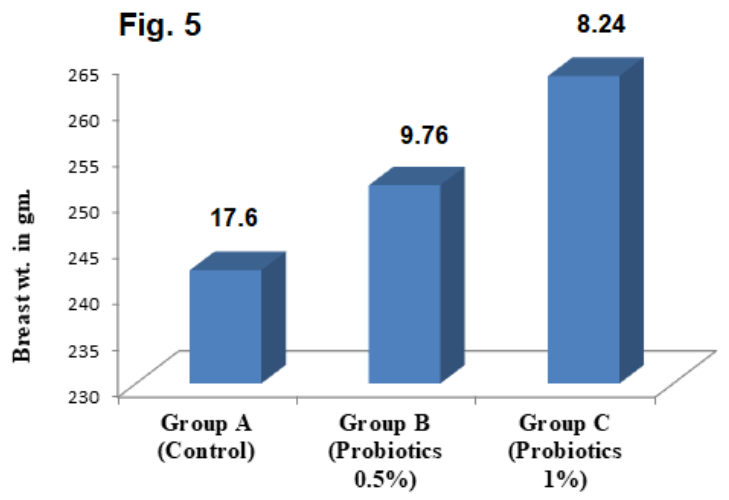

Fig. 7

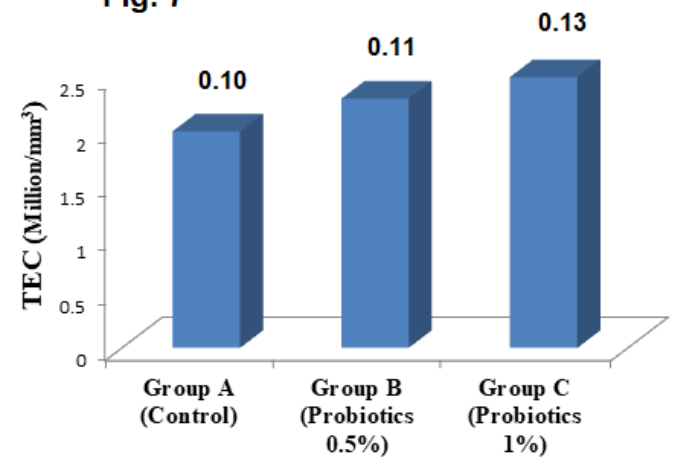

Fig. 6

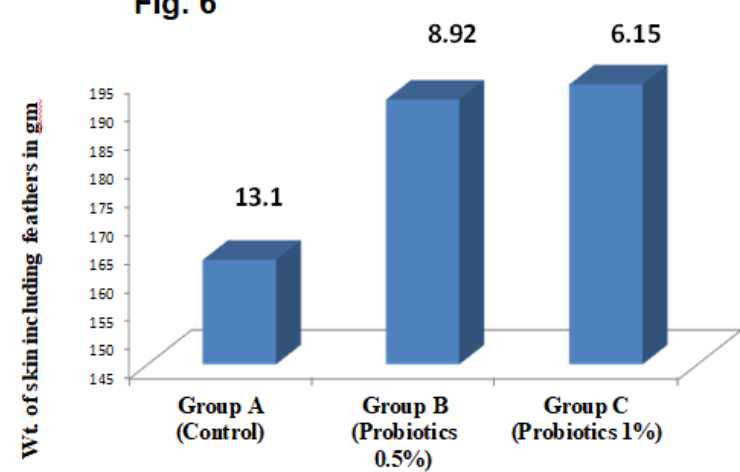

Fig. 8 0.07

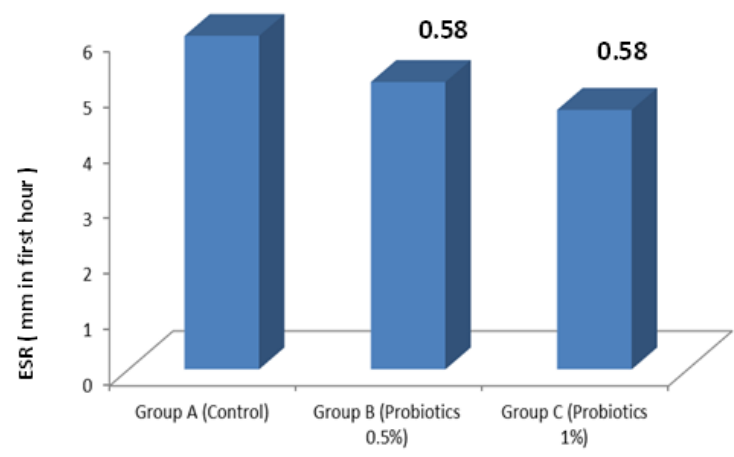

Figure 5. Effects of Probiotics on breast weight (mean $\pm \mathrm{SE}$ ) of broiler. Superscript value above bar indicate standard error; Figure 6. Effects of Probiotics on skin weight including feathers (mean $\pm \mathrm{SE}$ ) of broiler. Superscript value above bar indicate standard error; Figure 7. Effects of Probiotics on total erythrocyte count (mean \pm SE) of broiler. Superscript value above bar indicate standard error; Figure 8. Effects of Probiotics on erythrocyte sedimentation rate (mean $\pm \mathrm{SE}$ ) of different groups of broiler. Superscript value above bar indicate standard error.

\section{Effects on bio-chemical parameters}

The serum bio-chemical parameters are presented in table 4 and figure 10,11, 12 and 13.

Table 4. Mean \pm SE serum biochemical parameters in broilers

\begin{tabular}{|lllll|}
\hline Broiler Groups & $\begin{array}{l}\text { Triglyceride } \\
(\mathbf{m g} / \mathbf{d L})\end{array}$ & $\begin{array}{l}\text { Total cholesterol } \\
(\mathbf{m g} / \mathbf{d L})\end{array}$ & HDL(mg/dL) & $\begin{array}{l}\text { Alkaline } \\
\text { phosphate(U/L) }\end{array}$ \\
\hline Group A (Control) & $102.41 \pm 2.17^{\mathrm{a}}$ & $207.08 \pm 7.71^{\mathrm{a}}$ & $106.8 \pm 65.96^{\mathrm{a}}$ & $264.45 \pm 55.65^{\mathrm{b}}$ \\
Group B (Probiotics 0.5\%) & $64.66 \pm 8.46^{\mathrm{b}}$ & $202.72 \pm 6.11^{\mathrm{ab}}$ & $50.73 \pm 6.90^{\mathrm{b}}$ & $464.37 \pm 74.83^{\mathrm{a}}$ \\
Group C (Probiotics 1\%) & $74.90 \pm 10.93^{\mathrm{b}}$ & $192.92 \pm 0.24^{\mathrm{b}}$ & $48.53 \pm 5.41^{\mathrm{b}}$ & $384.20 \pm 19.93^{\mathrm{a}}$ \\
P value & 0.003 & 0.055 & 0.001 & 0.012 \\
Level of sig. & Significant & Non significant & Significant & Non significant \\
\hline
\end{tabular}

Values with different superscript litter(s) in the same column differ significantly $(P<0.05)$ 
Serum triglyceride (mean \pm SE) in all groups of broilers is presented in Table 4 and Figure 10. Serum triglycerides of control and Probiotic groups were 102.41 $\pm 2.17,64.66 \pm 8.46$ and $72.90 \pm 10.93 \mathrm{mg} / \mathrm{dl}$, respectively. Significantly $(p<0.05)$ higher triglyceride was found in control group compared to all others. Mansoub (2011) showed that the level of triglyceride in the groups (Triglyceride $1=153.74$, Triglyceride $2=121.46$, Triglyceride $3=122.64 \mathrm{mg} / \mathrm{dl}$ ) respectively which are differ in this findings.

Total cholesterol (mean \pm SE) in all groups of birds is presented in Table 4 and Figure 11. Total cholesterol of control and Probiotics group were $207.08 \pm 7.71,202.72 \pm 6.11$ and $192.92 \pm 0.24 \mathrm{mg} / \mathrm{dl}$, respectively. The highest total cholesterol was in control group. Total cholesterol decreased significantly $(p<$ 0.05 ) in the treated groups compared to control group. The present result is resembles to Mohon et al., (1996) who found that the serum cholesterol was significantly $(p<0.01)$ decreased.

High density lipoprotein (mean \pm SE) in all groups of birds is presented in Table 4 and Figure 12. High density lipoproteins of control and probiotics groups were 106.8 $\pm 65.96,50.73 \pm 6.90$ and $48.53 \pm 5.41 \mathrm{mg} / \mathrm{dl}$ respectively. Lowest serum HDL was found in group $\mathrm{C}$ and highest in group $\mathrm{A}$. In the treated groups there was insignificant change between two groups. HDL value lower in group $\mathrm{C}$ and compared to group $\mathrm{B}$. The present findings also differ from Kwan et al., (2002) who stated that HDL cholesterol was not significantly differed between the control group and probiotics treated group.

Fig. 9

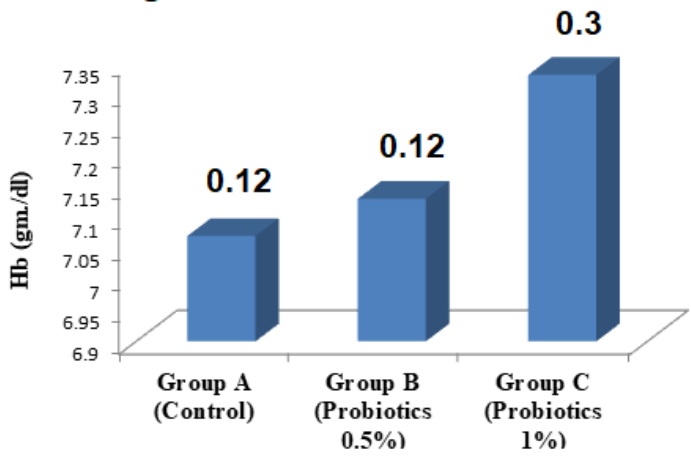

Fig. 11

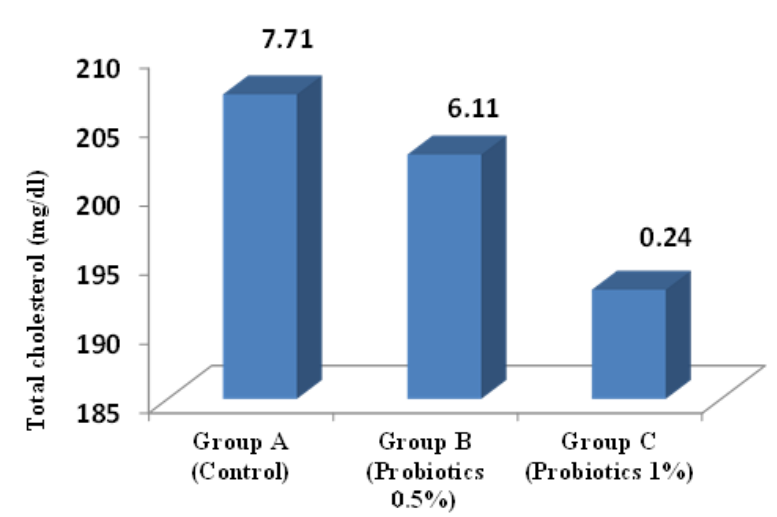

Fig. 10

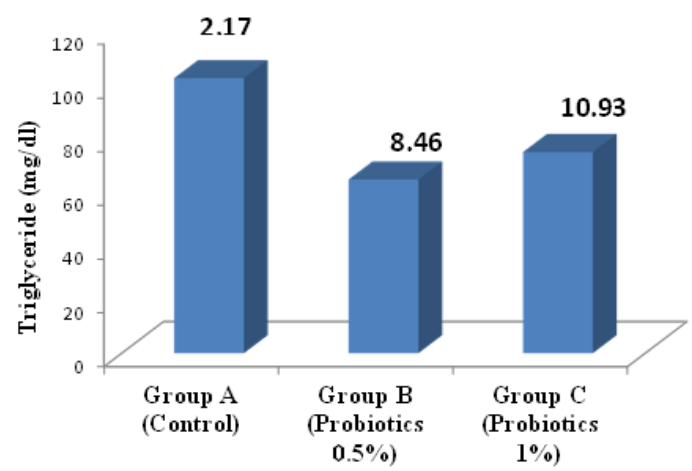

Fig. 12

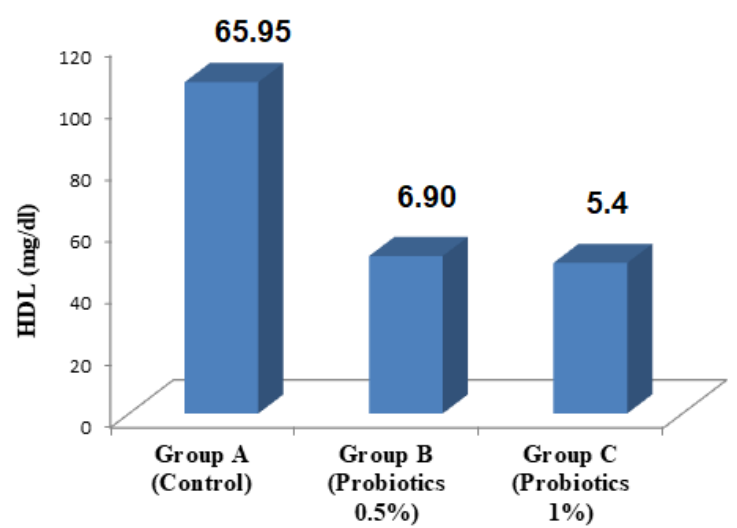

Figure 9. Effects of Probiotics on hemoglobin content (mean \pm SE) of different groups of broiler. Superscript value above bar indicate standard error; Figure 10. Effects of Probiotics on serum triglyceride (mean $\pm \mathrm{SE}$ ) of broiler. Superscript value above bar indicate standard error; Figure 11. Effects of Probiotics on total serum cholesterol (mean \pm SE) of broiler. Superscript value above bar indicate standard error; Figure 12. Effects of Probiotics on high density lipoprotein (mean $\pm \mathrm{SE}$ ) of broilers. Superscript value above bar indicate standard error. 
The serum alkaline phosphatase (mean \pm SE) in all groups of birds is presented in Table 4 and Figure 13. The alkaline phosphatases of control and probiotics groups were $264.45 \pm 55.65,464.37 \pm 74.83$ and $384.20 \pm$ $19.93 \mathrm{mg} / \mathrm{dl}$ respectively. Highest alkaline phosphatase was found in group B and lowest in control group. In the treated groups there was insignificant change between two groups. Serum alkaline phosphatase value lower in group C compared to group B. The findings correlated with the observation of Islam et al., (2004) who stated that supplementation of probiotics had significant $(p<0.01)$ influence on alkaline phosphatases.

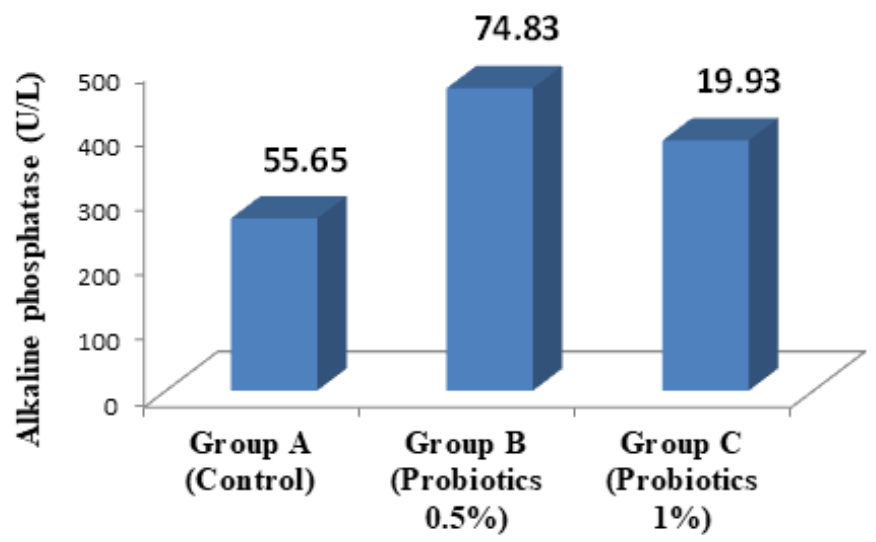

Figure 13. Effects of Probiotics on serum alkaline phosphatase (mean \pm SE) of broilers. Superscript value above bar indicate standard error.

\section{CONCLUSION}

The research work was conducted to investigate the effect of probiotics on "Cobb-500" broiler chicks to find out growth performances and haemato-biochemical values. Total body weight gain and weight of different organs was higher in treated groups. Moreover Hematological parameters improved in treated groups. Total cholesterol value was higher in control groups compared to probiotic treated groups. Serum triglyceride of treated groups were decreased significantly $(p<0.01)$ compared to control group. HDL value of treated groups were decreased significantly $(p<0.01)$ compared to control group. The Alkaline Phosphatase value was increased significantly $(p<0.01)$ in treated group compare to control. Further study using more birds with more groups along with histo-pathological changes in vital organs should be needed for making conclusions in the use of probiotics in birds.

\section{REFERENCES}

1. Baidya N, Mandal L, Sarkar SK, Banerjee GC 1994. Combined feeding of antibiotic and probiotic on the performance of broiler. Indian Journal of Poultry Science, 29(3): 228-231.

2. Datta J, 2013. Effect of feeding probiotic (bio-top) with or without an antibiotic growth promoter on broiler performance, Journal of animal Physiology and Animal Nutrition, 95(4): 424-433.

3. Dhawale 2005. Influence of Organic Acids Supplementation to the Diet on Functioning of the Digestive System in Laying Hens. Arch.Geflugelk., 77(3): 155-159.

4. Gomez K.A. and A.A. Gomez 1984. Ducans multiple Range test. Statiscal procedures for agricultural Research. Second edition. John Wiley and Sons, 207-215.

5. Green and Sainsbury 2001. Living microorganisms which, given to animals, assist to establishment of an intestinal population which is beneficial to the animal and antagonist to harmful microbes. Journal of Microbiology, 53(1): 91-99. 
6. Hamid MS, A Qureshi, 2001. Trial study on the efficiency of protexin (water soluble) on the performance of broiler. Pakistan Veterinary Journal, 21(4): 224-225.

7. Holoubek 1993. Stated that the probiotics, lactigerm, proms and biostrong improve feed conversion in broilers in comparison with un-supplemental control diets. International Journal of Poultry Science, 2(4): 322-324.

8. Interaction with Delayed Feed Access after Hatch on Broiler Growth Performance and Intestinal Health. Veterinary Medicine, 57(10): 515- 528.

9. Islam M., W. Rahman, M. M. Kabir, S. M. L. Kamruzzaman and M. N. Islam 2004. Effect of Probiotics Supplementation on Growth Performance and Certain Haemato-Biochemical parameters in Broiler Chicken. Bangladesh Journal of Veterinary Medicine, 2: 39-43.

10. Kamruzzaman SM, Kabir SML, Rahman MM, Isla M, Reza MA 2005. Effect of probiotics and antibiotic supplementation on body weight and hematobiochemical parameters in broiler. Bangladesh Journal of Veterinary Medicine, 3(2): 100-104.

11. Kwan OS, IH Kim, JW Hong, HK Hown and JM Lee, 2002. Effects on probiotics supplementation on growth performance, blood composition, and fecal noxious gas of broiler chickens. American Journal of Poultry Science, 29 (1): 1-6.

12. Mansoub NH, 2011. Comparative Effects of Using Garlic as Probiotic on Performance and Serum Composition of Broiler Chickens. Annals of Biological Research, 2 (3): 486-490.

13. Mohan B, Kadirevel R, Natarajan A and Bhaskaran M, 1996. Effect of probiotic supplementation on growth, nitrogen utilization and serum cholesterol in broilers. British Poultry Science, 37: 395-401.

14. Patten and Waldroup, 1988. Influence of Organic Acid Blend Supplementation and Interaction with Delayed Feed Access after Hatch on Broiler Growth Performance and Intestinal Health. Veterinary Medicine, 57(10): 515-528.

15. Pelicano ERL, Souza PA de, Souza HBA de, Oba A, Norkus EA, Kodawara LM, Lima TMA de, 2003. Effect of different probiotics on broiler carcass and meat quality. Revista Brasileira de Ciencia Avicola, 5 (3).

16. Philips, 1999. The Effects of Antibiotic Growth Promoter, Probiotic or Organic Acid Supplementation on Performance, Intestinal Microflora and Tissue of Broilers. International Journal of Poultry Science, 5(2): 149-155. 